УДК 745.52:

[687.016:687.12]

DOI:10.30857/2617-

0272.2019.4.7.
ПАШКЕВИЧ К.Л., ЄЖОВА О.В., КРОТОВА Т.Ф., КРЕДЕНЕЦЬ Н.Д., ЛЮ ЦЗЯНСІНЬ, ФЕСЮК І.Я.

Київський національний університет технологій та дизайну

\section{ДИЗАЙН-ПРОЕКТУВАННЯ СУЧАСНИХ СУКОНЬ 3 ОЗДОБЛЕННЯМ З УРАХУВАННЯМ ВЛАСТИВОСТЕЙ ТКАНИН}

Мета. Дослідження особливостей дизайн-проектування одягу з оздобленням з урахуванням властивостей тканин.

Методологія. Застосовано системний підхід, методи системно-структурного та морфологічного аналізу.

Результати. Проаналізовано актуальні колекції моделей жіночого одягу сучасних дизайнерів, визначено сучасні тенденції моди у виготовленні та оздобленні платтяних тканин та виробів з них, надано класифікацію різновидів оздоблення одягу. Визначено частоту зустрічності різних видів оздоблення у колекціях світових дизайнерів за 2011-2019 рр. Досліджено фізикомеханічні властивості зразків платтяних тканин: товщина, поверхнева густина, розривні характеристики та встановлено взаємозв'язки між ними. Надано рекомендації щодо вибору тканин для розробки сучасних жіночих суконь з використанням різноманітного оздоблення (плоского, об'ємного).

Наукова новизна. Встановлено взаємозв'язки між фізико-механічними показниками платтяних тканин та надано рекомендації щодо вибору тканин для створення сучасних жіночих суконь з використанням оздоблення на засадах тектонічного підходу.

Практична значущість. Проведений комплекс наукових досліджень щодо дизайнпроектування жіночих суконь на основі тектонічного підходу і визначення фізико-механічних показників платтяних тканин $\epsilon$ основою для розробки рекомендацій щодо вибору тканин для виготовлення суконь з різноманітним оздобленням.

Ключові слова: декор, фізико-механічні властивості тканини, фешн-індустрія, 3D друк, поверхнева густина.

Вступ. Дизайн-проектування одягу це комплексне завдання, яке поєднує технологічні та мистецькі складові. Для виготовлення естетичного, конкурентоспроможного одягу необхідно удосконалювати сучасні підходи до дизайнпроектування одягу, вибору матеріалів, технології обробки та впроваджувати інновації у процес виробництва [6].

Одне із основних завдань, яке стоїть перед фахівцями фешн-індустрії в даний час, - це застосування досягнень науки, техніки та мистецтва у створенні модного одягу враховуючи тенденції моди.

Дизайн одягу містить розробку таких елементів костюма: стильове рішення, силует, об'ємність форми, покрій рукава, конструктивно-декоративні елементи, членування, довжину виробу, а також оздоблення.

Цього року світові Будинки мод представили велику кількість колекцій одягу, в яких використані сучасні технології оздоблення: металеву фурнітуру, тканини 3 перфорацією, аплікації, різноманітну вишивку тощо. Застосування різноманітного оздоблення, яке широко використовується в одязі різного асортименту і призначення, потребує урахування властивостей тканин, тому удосконалення процесу дизайнпроектування сучасного одягу 3 оздобленням на основі дослідження властивостей тканин $\epsilon$ актуальним завданням.

Аналіз попередніх досліджень. Під поняттям «оздоблення» швейних виробів 
розуміють, перш за все, зовнішнє прикрашання одягу у вигляді аплікації, вишивки, тасьми, складок тощо, або художнє оздоблення текстильних матеріалів за рахунок використання різних видів переплетень, видів сировини тощо, поверхневого оздоблення мерсеризацією, фарбуванням, друкуванням, тисненням, ворсуванням тощо.

В роботі [5] виконано аналіз сучасних модних тенденцій в оформленні одягу, розглянуто особливості та способи декорування, технологічні прийоми художньої вишивки, наведено огляд сучасних і традиційних технік вишивки.

В роботі [10] авторами проаналізовано художньо-декоративне оздоблення в колекціях сучасних українських та світових дизайнерів, розглянуто принципи адаптації оздоблення та декору в колекціях de luxe для забезпечення їx конкурентоспроможності на фешн-ринку.

Автори статті [13] дослідили лазерну технологію нанесення зображення на матеріал, найбільш оптимальні режими лазерного гравірування, процес виготовлення виробів, декорованих за допомогою лазера. Дослідники [1] розглянули застосування 3D-друку у текстильному виробництві.

В роботі [8] запропоновано принципи дизайн-проектування колекції жіночого одягу із використанням оздоблення в техніці вибійки на основі аналізу і застосування основних ознак еко-стилю та дослідження фізико-механічних властивостей лляних тканин.

У статті [11] досліджено асортимент джинсового одягу, розглянуто традиційне і інноваційне декоративне оздоблення джинсових виробів, встановлено взаємозв'язки між фізико-механічними показниками джинсових тканин та тектонічною формою одягу.

Проведений аналіз показав, що удосконаленням процесу дизайнпроектування, виготовлення та художнього оздоблення одягу 3 оздобленням займаються багато дослідників, що пов'язано 3 постійним удосконаленням цього сегменту готового одягу. Виникнення нових способів оздоблення тканин та виробів, використання високотехнологічного обладнання, зміна напряму моди вимагають дослідження особливостей дизайн-проектування одягу 3 оздобленням на засадах тектонічного підходу.

Постановка завдання. Метою статті $\epsilon$ дослідження особливостей дизайнпроектування одягу 3 оздобленням на засадах тектонічного підходу.

Результати дослідження. Аналіз видів оздоблення показав, що його можна розділити на плоске, об'ємне та додаткові аксесуари [4, 7]. Плоске оздоблення виконується безпосередньо на поверхні деталей виробу, при цьому просторова форма матеріалу не змінюється. Об'ємне оздоблення формує та видозмінює об'ємну форму виробу і окремих його деталей за рахунок зміни просторового розташування матеріалів. Додаткові аксесуари одягу - це оздоблювальні деталі: шарфи, краватки, квіти, кокільє, жабо, коміри, манжети, пояси тощо. Часто в одному виробі застосовують кілька видів оздоблення, однак це вимагає їх узгодження, щоб не порушувати цілісності композиційного рішення. Також оздоблення часто $\epsilon$ творчим джерелом дизайнера для створення нових образів, моделей одягу, підкреслюючи ексклюзивність виробу та, в деяких випадках, функціональне призначення виробів. В сучасному моделюванні одягу використовуються різноманітні види оздоблення як комбіновано, так і окремо. Аналізуючи використання оздоблення одягу в цілому, можна розділити його за призначенням, а саме: для акцентування форми виробу або певних його частин, членування форми на частини, об'єднання частин форми або декількох самостійних форм. Оздоблення зазвичай ув'язане з загальним художньо- 
конструктивним рішенням виробу, з його лініями, формами, тканиною, конструкцією, узгодженістю в кольорі.

Велике розмаїття оздоблення характерне для виробів високої моди і індивідуального попиту, для яких традиційно вишуканою прикрасою $\epsilon$ такі види обробки як вишивка (нитками, бісером, стеклярусом, перлинами, пайєтками, стрічками), аплікація (полягає в отриманні зображення шляхом вирізання, нашивання або наклеювання елементів на тканину), перфорація (проста, неповна (часткова), багатошарова, 3 плетінням, 3 інкрустацією тощо), нові методи фарбування, друкування тощо.

$$
\text { Оздоблення одягу }
$$

можна

класифікувати за такими ознаками:

1) за асортиментом: аплікація, вишивка, оздоблювальні строчки і шви, фурнітура, оздоблення шнуром, бейкою тощо;

2) за способом виготовлення: поверхнева обробка, об'ємне оздоблення, додаткові аксесуари;

3) за способом дії на матеріал: механічний вплив, фізико-хімічний вплив, комбінована дія;

4) за способом з'єднання: ниткове, клейове, зварне, закльопковий спосіб, фіксація за допомогою ВТО тощо.

Проаналізувавши останні модні тенденції можна визначити основні тренди в жіночому одязі: середня та велика об'ємні форми одягу; сорочковий або суцільнокроєний рукави. В тренді залишаються сукні силуетів oversize, hyperform, А-силует та піщаний годинник. Одним 3 основних оригінальних прийомів, за допомогою якого дизайнери досягають оригінальності виробу, $\epsilon$ асиметрія, що проявляється у вигляді відсутності одного рукава, нерівного низу виробу, оголеного плеча тощо. Актуальною довжиною суконь $\epsilon$ міді та максі. Аналізуючи сучасну моду можна відзначити, що сьогодні споживачі повертаються до виробів, в яких використано оздоблення ручної роботи, не дивлячись на те, що високотехнологічні інженерні розробки швидко розвиваються і впроваджуються інновації у виготовленні швейних виробів. Проте, в даний час все більшу увагу привертає оздоблення, яке поєднує елементи ручної роботи і нові методи його виготовлення (зварювання, склеювання, лазерна обробка тощо). Інноваційні види оздоблення отримують за допомогою інноваційних пристроїв, а саме: лазерного друку, 3D-друку тощо. Технологію 3D-друку в своїх колекціях використовують дизайнери та Будинки високої моди Iris van Herpen, Mike Schmidt, Julia Daviy, Alexis Walsh, Danit Peleg та інші. Способом 3Dдруку виготовляють деталі для одягу 3 пластику, фотополімеру, паперу, гіпсу та металу. Одяг, роздрукований на 3Dпринтері, відрізняється від звичайного тим, що потребує «технічної зборки» та ускладнює рух, але 3 часом з'явилася можливість виготовляти більш еластичні і гнучкі деталі $[2,9]$.

Оздоблення залежить від сучасного напряму моди. Проведений аналіз колекцій світових дизайнерів показав, що у цьому сезоні часто використовують різноманітне, у тому числі інноваційне, оздоблення (вишивку, аплікації, лазерну перфорацію, порізи, печворк, складки, буфи, рюші, 3Dдруку тощо) (рис. 1).

Особливу увагу в цьому сезоні дизайнери приділили оздобленню, якому притаманна не лише декоративна, а й практична функція. Декор $\epsilon$ важливим елементом сучасної моди, а саме вишивка, різноманітні рисунки на тканині, декоративні елементи, аплікації, бахрома, мереживо, драпірування, волани, накладні кишені, банти тощо. Актуальні тенденції асортименту матеріалів цього сезону: натуральна та штучна шкіра, джинс, плівка, атлас, шовк, оксамит, трикотаж, замша, велюр. Кольорами Pantone в сезоні осіньзима 2019-2020 рр. стали: Chili Pepper (Перець чилі); Biking Red (Червоний 
велосипед); Crème de Pêche (Персиковий

(Темний чеддер); Bluestone (Сіро-голубий крем); Rocky Road (Кам'яна дорога); Fruit Dove (Фруктовий голуб); Dark Cheddar (Горлиця).

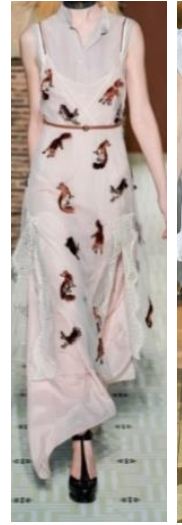

$a$

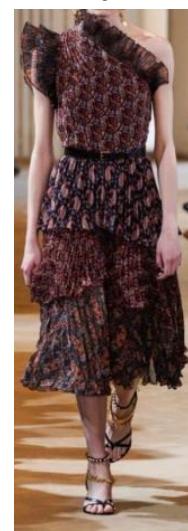

ж

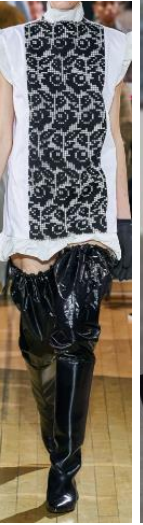

6

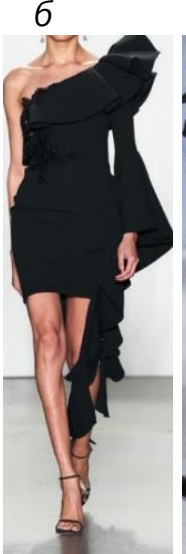

3
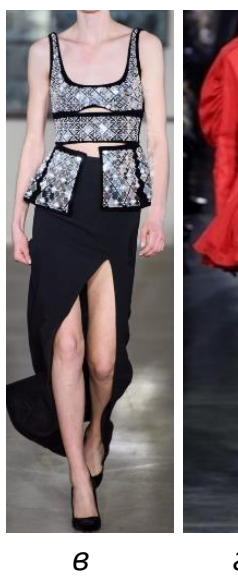

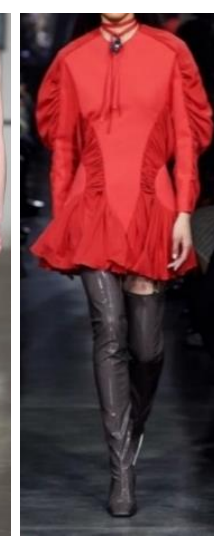

2

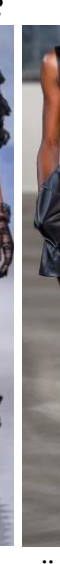

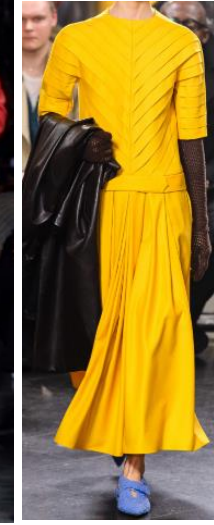

$\partial$

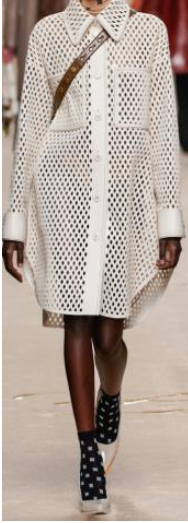

e

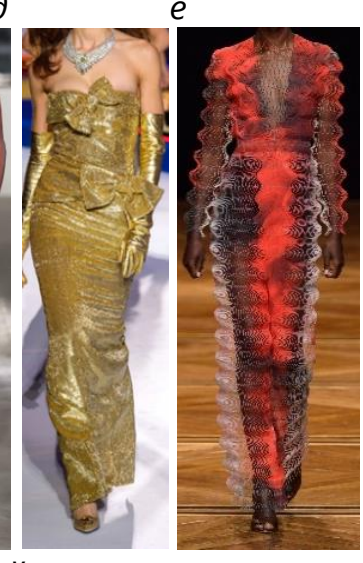

K

Рис. 1. Приклади оздоблення суконь сезону FW19/20: а - аплікації, Lanvin; б - вишивка, TOGA; в стрази, David Koma; г - драпірування, Mugler; д-складки, Emilia Wickstead; е - перфорація, Fendi; ж плісе, Altuzarra; з - волани, Pamella Roland; i - рюші, Shrimps; ї - накладні кишені, Balenciaga; й банти, Moschino; к - 3D друк, Iris van Herpen [12]

3 метою виявлення найбільш популярних видів оздоблення жіночого одягу проведено аналіз близько 500 моделей суконь в колекціях світових дизайнерів на сайті журналу Vogue. Для дослідження обрано два часові періоди: 2011-2015 рр. та 2016-2019 рр. Результати дослідження частоти зустрічності видів оздоблення наведено в табл. 1.

Встановлено, що найчастіше для оздоблення суконь як у 2011-2015 рр., так і у 20162019 рр. дизайнери використовували принти (26\% та 27\% відповідно), вишивку (23\% та 19\% відповідно), складки (15\% та 15\% відповідно), рюші (13\% та 12\% відповідно) та аплікацію. Як видно із табл. 1 у 2016-2019 рр. використання принтів для оздоблення суконь збільшилося (на 1 \%), у той час як використання вишивки зменшилося (на 4 \%). Для оздоблення жіночих суконь, згідно результатам проведеного дослідження, дизайнери частіше використовують перфорацію тканини (5\% у 2011-2015 рр. та 6 \% у 2016-2019 рр.). Також в 2016-2019 рр. значно частіше зустрічається 3D друк (4\%).

Однією з основних умов отримання високоякісних виробів $\epsilon$ правильний і обґрунтований вибір матеріалів 3 урахуванням призначення та конструктивних особливостей виробу, застосовуваних методів виготовлення тощо. Досвід показує, що для того, щоб наносити на тканину оздоблення, вона повинна бути міцною, тому при дизайн- 
проектуванні одягу з платтяних тканин з оздобленням необхідне дослідження властивостей тканини, щоб створити виріб, який відповідатиме потребам споживачів.

Таблиця 1

Результати дослідження частоти зустрічності видів оздоблення жіночих суконь

\begin{tabular}{|l|c|c|}
\hline \multirow{2}{*}{ Вид оздоблення } & \multicolumn{2}{|c|}{ Частота зустрічності, \% } \\
\cline { 2 - 3 } & $2011-2015$ рр. & 2016-2019 рр. \\
\hline Принти & 26 & 27 \\
\hline Вишивка & 23 & 19 \\
\hline Складки & 15 & 15 \\
\hline Рюші & 13 & 12 \\
\hline Аплікація & 11 & 12 \\
\hline Перфорація & 5 & 6 \\
\hline Плісе & 5 & 5 \\
\hline 3D-друк & 2 & 4 \\
\hline
\end{tabular}

Нами відібрано дев'ять зразків платтяних тканин різного сировинного складу, що відрізняються за зовнішнім виглядом і фізико-механічними характеристиками та визначено такі фізикомеханічні показники: товщину, поверхневу густину, розривне подовження і розривне навантаження.

За ГОСТ 12023-2003 за допомогою ручного товщиноміру індикаторного типу TP 10-1 визначено товщину платтяних тканин [14]. Для проведення досліду вирізано по 6 елементарних проб в поздовжньому та поперечному напрямках. Дослідження розривного навантаження та розривного подовження проведено за ГОСТ 3813-72 стандартним стріп-методом [15]. Напівциклові характеристики матеріалів при одноосьовому розтягуванні визначено на розривній машині РТ-250 (ширина зразків 50 мм, довжина - 200 мм).

Для виготовлення суконь 3 оздобленням зазвичай зміцнюють тканину клейовим прокладковим матеріалом, який завдяки своїм властивостям змінює фізикомеханічні характеристики платтяних тканин.

Для порівняння властивостей платтяних тканин окрім основних не дубльованих зразків тканин (Ф0) підготовлено по три зразка кожної тканини в поздовжньому і поперечному напрямках по основі та по утоку, які продубльовано двома видами флізеліну: флізелін клейовий

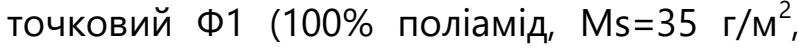
колір білий) і флізелін клейовий точковий Ф2 (50\% поліамід і 50\% поліестер, Ms=36 г/м², колір білий).

$$
\text { Отримані в результаті }
$$
експериментального дослідження фізикомеханічні показники та характеристики платтяних тканин узагальнено в табл. 2, табл. 3. В строках 10 та 11 табл. 3 наведено характеристики флізелінів Ф1 та Ф2.

Порівняння отриманих даних товщини та поверхневої густини досліджуваних платтяних тканин надано на рис. 2. В середньому поверхнева густина досліджених тканин коливається від 80 до 220 г/M², що відповідає нормативним значенням для платтяних тканин, наданих в літературі [6]. Як видно на гістограмі (рис. 2) поверхнева густина тканини прямо пропорційна її товщині, тобто зі зростанням товщини тканини зростає і показник їі поверхневої густини: зразки 1, 2, 5 та 9 мають найбільшу товщину, відповідно і поверхнева густина їх найбільша. Порівняння величин розривного подовження та розривного навантаження платтяних тканин без флізелину по основі та утоку надано на рис. 3. 
Таблиця 2

\section{Основні фізико-механічні характеристики платтяних тканин}

\begin{tabular}{|c|c|c|c|c|c|}
\hline $\begin{array}{c}\text { № } \\
\text { зразка }\end{array}$ & $\begin{array}{c}\text { Сировинний склад, } \\
\%\end{array}$ & Переплетення & Maca, r & $\begin{array}{l}\text { Товщина, } \\
\text { мм }\end{array}$ & $\begin{array}{c}\text { Поверхнева } \\
\text { густина, } \\
\text { г/м }{ }^{2}\end{array}$ \\
\hline 1 & $\Pi E-100$ & Атласне & 1,98 & 0,34 & 198 \\
\hline 2 & $\begin{array}{l}\text { бавовна - 95, } \\
\text { еластан - } 5\end{array}$ & Атласне & 1,91 & 0,37 & 191 \\
\hline 3 & ПЕ - 95, еластан - 5 & Атласне & 1,44 & 0,30 & 144 \\
\hline 4 & ПЕ - 97, еластан - 3 & Атласне & 1,77 & 0,31 & 177 \\
\hline 5 & $\begin{array}{l}\text { ПЕ - 60, бавовна - } \\
40\end{array}$ & Атласне & 2,02 & 0,37 & 202 \\
\hline 6 & $\begin{array}{l}\text { ПЕ - 60, віскоза - } \\
30, \text { бавовна }-10\end{array}$ & Полотняне & 1,50 & 0,30 & 150 \\
\hline 7 & $\begin{array}{l}\text { бавовна - 80, } \\
\text { віскоза }-20\end{array}$ & Полотняне & 0,85 & 0,21 & 85 \\
\hline 8 & $\Pi E-100$ & Полотняне & 0,71 & 0,20 & 71 \\
\hline 9 & $\Pi E-100$ & Саржеве & 2,20 & 0,50 & 220 \\
\hline
\end{tabular}

Таблиця 3

Розривні характеристики текстильних матеріалів

\begin{tabular}{|c|c|c|c|c|c|c|c|c|c|c|c|c|}
\hline \multirow{3}{*}{$\begin{array}{c}\text { № } \\
\text { зразка }\end{array}$} & \multicolumn{6}{|c|}{ Розривне подовження, мм } & \multicolumn{6}{|c|}{ Розривне навантаження, Н } \\
\hline & \multicolumn{2}{|c|}{$\begin{array}{c}\text { Без } \\
\text { флізеліну } \\
(Ф 0) \\
\end{array}$} & \multicolumn{2}{|c|}{$\begin{array}{c}1 \text { вид } \\
\text { флізеліну } \\
(Ф 1) \\
\end{array}$} & \multicolumn{2}{|c|}{$\begin{array}{c}2 \text { вид } \\
\text { флізеліну } \\
\text { (Ф2) }\end{array}$} & \multicolumn{2}{|c|}{$\begin{array}{c}\text { Без флізеліну } \\
\text { (Ф0) }\end{array}$} & \multicolumn{2}{|c|}{$\begin{array}{c}1 \text { вид } \\
\text { флізеліну } \\
(Ф 1)\end{array}$} & \multicolumn{2}{|c|}{$\begin{array}{c}2 \text { вид } \\
\text { флізеліну } \\
(Ф 2)\end{array}$} \\
\hline & $\begin{array}{l}\text { D } \\
0 \\
O \\
\text { T⿱亠乂 } \\
0\end{array}$ & $\begin{array}{l}\text { 흔 } \\
\text { 5 }\end{array}$ & $\begin{array}{l}\text { D } \\
0 \\
O \\
\text { İ } \\
0\end{array}$ & $\begin{array}{l}\text { \% } \\
\text { 은 }\end{array}$ & $\begin{array}{l}\text { ס } \\
0 \\
0 \\
\text { I } \\
\text { ப் } \\
0\end{array}$ & 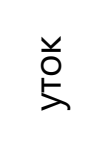 & 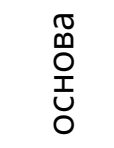 & $\begin{array}{l}\text { 흔 } \\
\text { 5 }\end{array}$ & 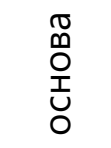 & $\begin{array}{l}\text { ㅎ } \\
\text { 5 }\end{array}$ & $\begin{array}{l}\text { D } \\
0 \\
0 \\
\text { I } \\
\text { O }\end{array}$ & $\begin{array}{l}\text { 흔 } \\
\text { 5 }\end{array}$ \\
\hline 1 & 67 & 52 & 59 & 50 & 66 & 46 & 1280 & 1758 & 1285 & 1783 & 1318 & 1780 \\
\hline 2 & 16 & 49 & 20 & 50 & 21 & 55 & 788 & 175 & 1178 & 215 & 1413 & 263 \\
\hline 3 & 71 & 60 & 79 & 77 & 84 & 74 & 693 & 560 & 703 & 618 & 730 & 610 \\
\hline 4 & 56 & 91 & 64 & 113 & 65 & 112 & 1380 & 678 & 1753 & 723 & 1773 & 693 \\
\hline 5 & 59 & 72 & 68 & 71 & 68 & 72 & 940 & 735 & 1003 & 868 & 928 & 938 \\
\hline 6 & 49 & 48 & 50 & 36 & 51 & 39 & 392 & 360 & 385 & 384 & 364 & 389 \\
\hline 7 & 48 & 39 & 38 & 50 & 44 & 6 & 222 & 228 & 261 & 241 & 286 & 270 \\
\hline 8 & 66 & 54 & 67 & 41 & 73 & 49 & 429 & 295 & 434 & 236 & 459 & 292 \\
\hline 9 & 69 & 61 & 81 & 74 & 85 & 72 & 1216 & 1178 & 1275 & 1253 & 1285 & 1200 \\
\hline 10 & \multicolumn{2}{|l|}{ 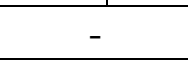 } & \multicolumn{2}{|c|}{35} & \multicolumn{2}{|c|}{40} & & \multicolumn{2}{|c|}{110} & \multicolumn{2}{|c|}{100} \\
\hline 11 & \multicolumn{2}{|c|}{ - } & \multicolumn{2}{|c|}{40} & \multicolumn{2}{|c|}{46} & \multicolumn{2}{|c|}{-} & \multicolumn{2}{|c|}{100} & \multicolumn{2}{|c|}{120} \\
\hline
\end{tabular}




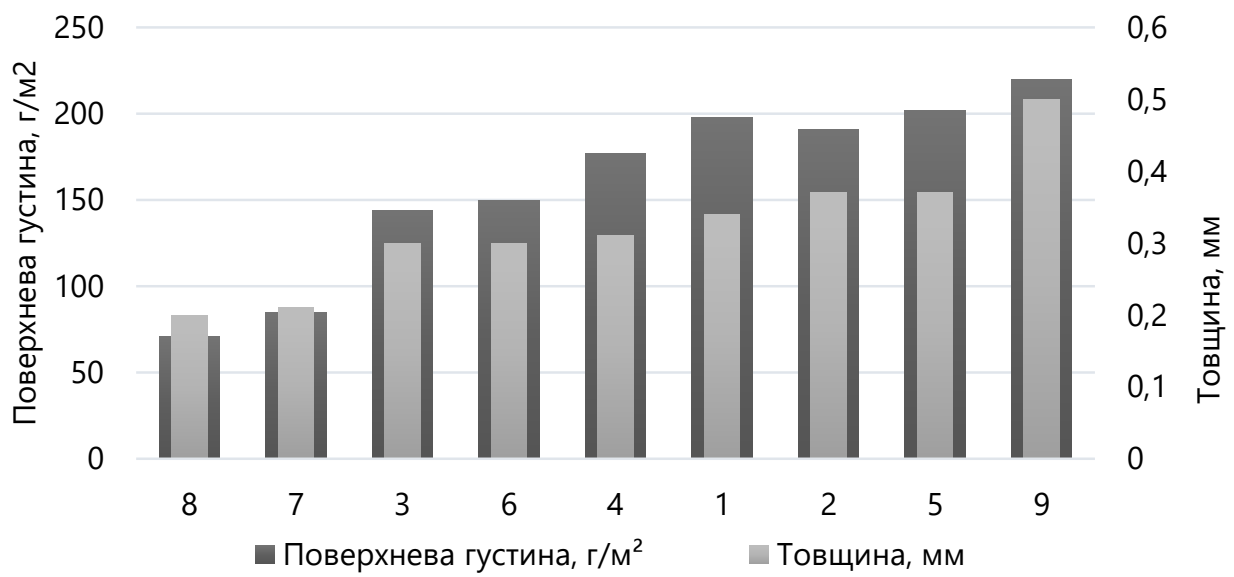

Рис. 2. Порівняння поверхневої густини та товщини платтяних тканин

п Ф0 основа, мм Ф1 основа, мм Ф2 основа, мм

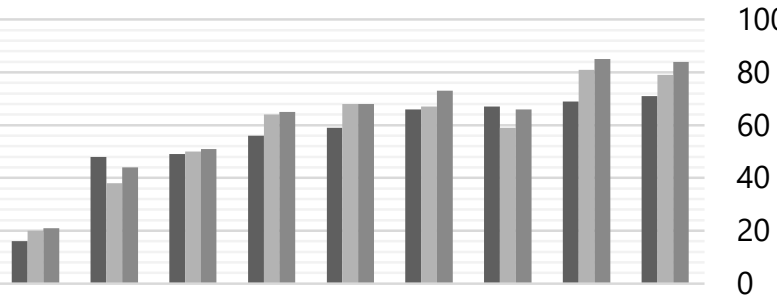

$\begin{array}{lllllllll}2 & 7 & 6 & 4 & 5 & 8 & 1 & 9 & 3\end{array}$
Ф0 уток, мм Ф1 уток, мм Ф2 уток, мм

a

6

Рис. 3. Порівняння розривного подовження та розривного навантаження платтяних тканин: а - по основі; б - по утоку

Визначено, що сировинний склад платтяних тканин впливає на показники розривного подовження i розривного навантаження, оскільки волокна тканин, що містять еластан, під час навантаження значно розтягуються.

Порівняння розривного навантаження платтяних тканин без флізелину показало, що найбільші показники розривного подовження по утоку мають зразки 3, 4, 5, 9, а по основі - зразки 1, 3, 8, 9.

Для порівняння властивостей досліджуваних платтяних тканин не дубльованих і дубльованих двома видами флізеліну визначена їх взаємозалежність по основі і по утоку (рис. 4, рис. 5). Визначено, що кращі властивості має флізелін Ф2, тому що зразки тканин, продубльовані ним, мають кращі розривні характеристики, вони міцніші. Аналіз результатів дослідження свідчить, що зразки, продубльовані флізеліном Ф2, мають більші показники розривного навантаження та розривного подовження, ніж зразки продубльовані флізеліном Ф1, тому флізелін Ф2 можна рекомендувати для використання у виробах 3 оздобленням, наприклад для вишивки. Також встановлено, що зразки 6, 7, 8 мають погані розривні характеристики, тому що мають малу поверхневу густину, і навіть використання дублювання цих тканин флізеліном не покращило їхніх показників. Результати дослідів показали, що в дубльованих зразках 3, 6, 7, 8 спочатку розривався флізелін, а потім тканина. 
Ф0 основа, мм Ф1 основа, мм Ф2 основа, мм

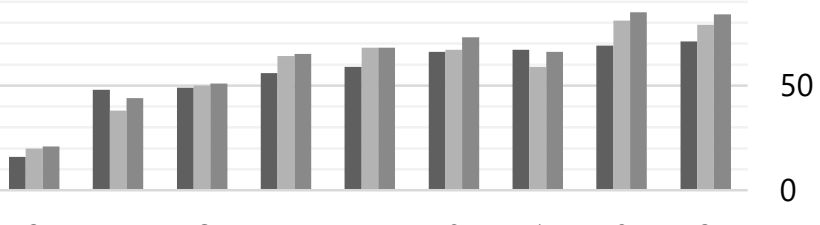

Ф0 уток, мм Ф1 уток, мм Ф2 уток, мм

100

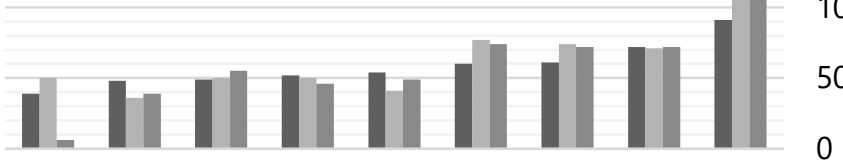

$\begin{array}{lllllllll}7 & 6 & 2 & 1 & 8 & 3 & 9 & 5 & 4\end{array}$

6

Рис. 4. Порівняння розривного подовження дубльованих платтяних тканин: а - по основі; б - по утоку

Ф0 основа, $\mathrm{H}$ Ф1 основа, $\mathrm{H}$ Ф2 основа, $\mathrm{H}$

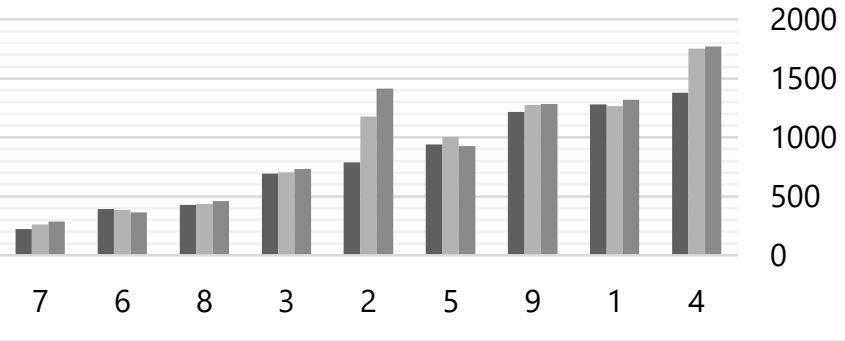

a
- Ф0 уток, $\mathrm{H} \quad$ - Ф1 уток, $\mathrm{H} \quad$ 口2 уток, $\mathrm{H}$ 2000 1500 1000 500 + -

Рис. 5. Порівняння розривного навантаження дубльованих платтяних тканин: а - по основі; б - по утоку

Проведено аналіз зразків досліджених тканин 3 метою надання рекомендацій щодо застосування певного виду оздоблення при виготовленні жіночих суконь. Тканини зразків 1, 3, 4, 5 атласного переплетення із синтетичних волокон, гладко-фарбовані. Для цих тканин доцільним $\epsilon$ використання різновидів плоского оздоблення, оскільки вони міцні за розривними характеристиками, жорсткі, погано драпіруються. Зразок номер 2 має сировинний склад 95\% бавовна, 5\% еластан, тканина гладко-фарбована 3 атласним переплетенням. Для цієї тканини доцільним $\epsilon$ використання об'ємного оздоблення. Тканини зразків 6 та 7 мають у сировинному складі бавовну з домішками синтетичних волокон, гладко-фарбовані, полотняного переплетення, тому для цих тканини можна рекомендувати такі види оздоблення: вишивка, аплікація, складки, фурнітура тощо. Зразок номер 8 - це шифонова тканини, що має полотняне переплетення, за сировинним складом 100\% ПЕ. Оскільки тканина тонка, з малою жорсткістю, на ній не рекомендується виконувати вишивку, об'ємну, важку аплікацію, а доцільним $\epsilon$ використання драпіровок, воланів, буфів та інших видів об'ємного оздоблення. Тканина зразка 9 - гладко-фарбована, саржевого переплетення, за сировинним складом 100\% ПЕ; для виробів 3 цієї тканини рекомендується використання різновидів плоского оздоблення, тому, що тканини за своїми характеристиками витримує певне навантаження від оздоблення.

Таким чином, можна рекомендувати платтяні тканини зразків 1, 4, 5 та 9 для виготовлення жіночих суконь 3 використанням різноманітного оздоблення (плоского і об'ємного), оскільки їх товщина, поверхнева густина і розривні 
характеристики відповідають даним потребам. Зразки 2, 3, 6 та 7 рекомендуються для виготовлення літніх суконь, наприклад, суконь у романтичному стилі 3 переважним використанням об'ємного оздоблення. Тканина зразка 8 рекомендується як додатковий матеріал для виготовлення суконь, або для виготовлення суконь без оздоблення.

Висновки. Розглянуто процес сучасного дизайн-проектування одягу 3 платтяних тканин, досліджено різновиди оздоблення одягу, визначено тенденції моди, інновації в декоративному оздобленні жіночих суконь. 3 метою виявлення найбільш популярних видів оздоблення жіночого одягу та частоти їх зустрічності проведено аналіз близько 500 моделей суконь в колекціях світових дизайнерів.

\section{Література}

1. Korger M., Bergschneider J., Lutz M., Mahltig B., Finsterbusch K., Rabe M. Possible Applications of 3D Printing Technology on Textile Substrates. IOP Conference Series: Materials Science and Engineering. Vol. 141, N. 1, 2016. P. 1-5. URL: https://iopscience.iop.org/article/10.1088/1757899X/141/1/012011.

2. Schniederjans Dara G. Adoption of 3Dprinting technologies in manufacturing: A survey analysis. International Journal of Production Economics. Vol. 183, Part A, 2017, P. 287-298. URL: http://www.journaliji.org/index.php/iji/article/view/ 393.

3. ГОСТ 3811-72 Материалы текстильные. Ткани, нетканые полотна и штучные изделия. Методы определения линейных размеров, линейной и поверхностной плотностей. Москва. Дата введения 1973-01-01.

4. Ергономіка i дизайн. Проектування сучасних видів одягу: навч. посібн. / М.В. Колосніченко, Л.І. Зубкова, К.Л. Пашкевич та інші. Київ: ПП «НВЦ «Профі», 2014. 386 с.

5. Камнева С.Ю. Современное искусство художественной вышивки: основные тенденции развития. Традиционное прикладное искусство и образование. №4, 2016. С. 11-19.
Визначено, що найчастіше в якості оздоблення зустрічаются принти та вишивка. Проведено дослідження зразків платтяних тканин та визначено їх фізикомеханічні показники: товщину, поверхневу густину, розривне навантаження і розривне подовження. Встановлено взаємозв'язки між фізико-механічними показниками платтяних тканин та розроблено рекомендації щодо дизайн-проектування жіночих суконь залежно від властивостей платтяних тканин. Перспективами подальших досліджень $\epsilon$ розгляд інноваційних технологій оздоблення суконь, надання науково обґрунтованих рекомендації щодо вибору тканин 3 певними властивостями при виготовленні колекцій одягу різного призначення.

6. Пашкевич К.Л. Проектування тектонічних форм одягу з урахуванням властивостей тканин: монографія. К.: ПП «НВЦ «Профі», 2015. 364 с.

7. Колосніченко М. В., Пашкевич К. Л. Мода і одяг. Основи проектування та виробництва одягу. К: КНУТД, 2018. 236 с.

8. Краснюк Л. В., Матрофайло М. В., Троян О. М. Проектування авторської колекції жіночого одягу в еко-стилі із використанням оздоблення в техніці вибійки. Art and Design. 2018, № 3 (03). C. 96-106. DOI: http://jrnl.knutd.edu.ua/index.php/ artdes/article/view/156.

9. Пашкевич К.Л. Нові технології: 3D принтер. Легка промисловість. 2014. №1. С. 22-25. URL: https://knutd.edu.ua/publications/pdf/Ukrainian_ed itions/2015/Pashkevich3D03122015.pdf.

10. Pashkevych K., Mihus R. The analysis of de luxe clothing in the collections of global and ukrainian designers. Вісник НАКKКIM, №3, 2019. C. 311-316.

URL: https://nakkkim.edu.ua/images/vidannya/Visnyk_N AKKKiM/Visnyk_3_19.pdf.

11.Пашкевич К. Л., Єжова О. В., Пастух Я. О., Роготченко О. О. Дизайн-проектування одягу 3 джинсових тканин на основі тектонічного підходу. Art and Design. №4, 2018. C. 83-94. DOI: http://jrnl.knutd.edu.ua/index.php/artdes/article/vie w/213. 
12.Сайт журнала Vogue. URL: https://www.vogue.com/ (дата звернення: 16.10.2019).

13.Хисамиева Л.Г., Петрова А.А., Гилязова А.А., Бадрутдинова А.Н. Декорирование поверхности и текстильных полимерных материалов с помощью лазерной технологии. Вестник Казанского технологического университета. 2012. Том 11. С. 127-128.

14. ГОСТ 12023-2003 Материалы текстильные и изделия из них. Метод определения толщины. Москва. 2003. Дата введения 2005-12-01.

15.ГОСТ 3813-72 Материалы текстильные. Ткани и штучные изделия. Методы определения разрывных характеристик при растяжении. Москва. Дата введения 1973-01-01.

\section{References}

1. Korger, M., Bergschneider, J., Lutz, M., Mahltig, B., Finsterbusch, K., Rabe, M. (2016). Possible Applications of 3D Printing Technology on Textile Substrates. IOP Conference Series: Materials Science and Engineering. Vol. 141, 1, 1-5. URL: https://iopscience.iop.org/article/10.1088/1757899X/141/1/012011.

2. Schniederjans, Dara G. (2017). Adoption of 3D-printing technologies in manufacturing: A survey analysis. International Journal of Production Economics, Vol. 183. A. 287-298. URL: http://www.journaliji.org/index.php/iji/article/view/ 393.

3. GOST 3811-72: Materialy tekstil'nye. Tkani, netkanye polotna i shtuchnye izdeliya. Metody opredeleniya lineynykh razmerov, lineynoy i poverkhnostnoy plotnostey [State Standard 381172: Textile materials. Fabrics, non-woven cloths and piece products. Methods for determining linear dimensions, linear and surface densities]. Moscow, Standartinform Publ. 14. [in Russian]

4. Kolosnichenko, M.V., Zubkova, L.I. \& Pashkevych, K.L. at al. (2014). Yergonomika I dizayn. Proyektuvannya suchasnikh vidív odyagu [Ergonomics and design. Designing modern types of clothing]. Kyiv: PP «NVTS «Profí [in Ukrainian].

5. Kamneva, S.Yu. (2016). Sovremennoe iskusstvo khudozhestvennoy vyshivki: osnovnye tendentsii razvitiya [Modern art of embroidery: the main trends] Traditsionnoe prikladnoe iskusstvo i obrazovanie, 4, 11-19. [in Russian].

6. Pashkevych K.L. (2015) Proektuvannia tektonichnykh form odiahu z urakhuvanniam vlastyvostei tkanyn [Designing of tectonic forms of clothing taking into account the properties of fabrics]. K.: PP «NVTs «Profi». 364. [in Ukrainian].

7. Kolosnichenko, M.V. \& Pashkevich, K.L. (2018). Moda i odyag. Osnovi proyektuvannya ta virobnitstva odyagu. [Fashion and clothing. Principles of designing and manufacturing of clothes]. Kyiv: KNUTD [in Ukrainian]

8. Krasniuk, L. V., Matrofailo, M. V., Troian, O. M. (2018). Proektuvannia avtorskoi kolektsii zhinochoho odiahu v eko-styli iz vykorystanniam ozdoblennia $v$ tekhnitsi vybiiky [Designing an author's collection of women's clothing in eco-style with the use of decoration in the technique of knockout] Art and Design. Kyiv, 3. 96-106. DOI: http://jrnl.knutd.edu.ua/index.php/artdes/article/vie w/156. [in Ukrainian].

9. Pashkevich, K. L. (2014). Novi tekhnolohii: 3D prynter [New technologies: 3D printer]. Lehka promyslovist, $\quad 1 . \quad 22-25 . \quad$ URL: https://knutd.edu.ua/publications/pdf/Ukrainian_ed itions/2015/Pashkevich3D03122015.pdf [in Ukrainian].

10.Pashkevych, K., Mihus, R. The analysis of de luxe clothing in the collections of global and ukrainian designers. Visnyk NAKKKIM, №3, 2019. C. 311-316.

URL: https://nakkkim.edu.ua/images/vidannya/Visnyk_N AKKKiM/Visnyk_3_19.pdf.

11.Pashkevych, K. L., Yezhova, O. V., Pastukh, Ya. O., Rohotchenko, O. O. (2018). Dyzainproektuvannia odiahu z dzhynsovykh tkanyn na osnovi tektonichnoho pidkhodu [Design-designing of clothes from denim fabrics on the basis of tectonic approach] Art and Design. Kyiv, 4, 83-94. DOI: http://jrnl.knutd.edu.ua/index.php/artdes/ article/view/213. [in Ukrainian].

12. Sait zhurnala Vogue [Site of journal Vogue]. URL: https://www.vogue.com (Last accessed: 16.06.2019).

13. Khisamieva, L.G., Petrova, A.A, Gilyazova, A.A., Badrutdinova, A.N. (2012). Dekorirovanie poverkhnosti i tekstil'nykh polimernykh materialov $s$ pomoshch'yu lazernoy tekhnologii [Surface decoration and textile polymer materials using laser technology] Vestnik Kazanskogo tekhnologicheskogo universiteta. Vol. 11, 127-128. [in Russian].

14.GOST 12023-2003: Materialy tekstil'nye i izdeliya iz nikh. Metod opredeleniya tolshchiny [State Standard 12023-2003. Textile materials. 
Fabrics, non-woven cloths and piece products. Methods for determining linear dimensions, linear and surface densities]. Moscow, Standartinform Publ. 11. [in Russian]

15.GOST 3813-72: Materialy tekstil'nye. Tkani i shtuchnye izdeliya. Metody opredeleniya

\section{ДИЗАЙН-ПРОЕКТИРОВАНИЕ СОВРЕМЕННЫХ ПЛАТЬЕВ С ОТДЕЛКОЙ С УЧЕТОМ СВОЙСТВ ТКАНЕЙ}

ПАШКЕВИЧ К.Л., ЕЖОВА О.В., КРОТОВА Т.Ф., КРЕДЕНЕЦЬ Н.Д., ЛЮ ЦЗЯНСИНЬ, ФЕСЮК И.Я.

Киевский национальный университет технологий и дизайна

Цель. Исследование особенностей дизайнпроектирования одежды с отделкой с учетом свойств тканей.

Методология. Использован системный подход, методы системно-структурного и морфологического анализа.

\section{Результаты.}

Проанализированы актуальные коллекции моделей женской одежды современных дизайнеров, определены современные тенденции моды в изготовлении и отделке плательных тканей и изделий из них, дана классификация видов отделки одежды. Определена частота встречаемости разных видов отделки в коллекциях мировых дизайнеров за 2011-2019 гг. Исследованы физико- механические свойства образцов плательных тканей: толщина, поверхностная плотность, разрывные характеристики и установлены взаимосвязи между ними. Разработаны рекомендации по выбору тканей для разработки современных женских платьев с использованием разных видов отделки (плоской, объемной).

Научная новизна. $\quad$ Установлены
взаимосвязи между физико-механическими
показателями плательных
разработаны реконей и
тканей для создания современных женских
платьев с использованием отделки на
основе тектонического подхода.

Практическая значимость. Проведенный razryvnykh kharakteristik pri rastyazhenii [State Standard 3813-72. Textile materials. Fabrics and items. Methods for determining discontinuous characteristics during stretching]. Moscow, Standartinform Publ. 14. [in Russian].

\section{DESIGN-PROJECTION OF MODERN DRESSES WITH FINISHING, CONSIDERING THE PROPERTIES OF FABRICS \\ PASHKEVYCH K.L., YEZHOVA O.V., KROTOVA T.F., KREDENETS N.D., LJU JIANGXIN FESYUK I.Ya. \\ Kyiv National University of Technologies and Design}

The purpose. To study the specifics of design-projection of clothes with finishing, considering the properties of fabrics.

Methodology. The system approach, as well as the methods of system-structural and morphological analysis, are used.

Results. The current collections of women's clothes, presented by modern designers, have been analyzed; the current fashion trends in manufacturing and finishing of dress fabrics and products, made from such fabrics, have been identified; the classification of types of finishing of clothes has been presented. The frequency of occurrence of different types of finishing in the collections of world-famous designers in 2011 - 2019 has been determined. Physical and mechanical properties of samples of dress fabrics have been studied, in particular: thickness, surface density, abruption characteristics; their interconnections have been identified. The recommendations on the selection of fabrics for the creation of modern women's dresses using different types of finishing (flat volumetric) have been developed.

Scientific novelty. The interconnections between physical and mechanical parameters of dress fabrics are identified, and the recommendations on the selection of fabrics for the creation of modern women's dresses using the finishing based on the tectonic approach are developed. 
комплекс научных исследований по дизайн-проектированию женских платьев на основе тектонического подхода и определению физико-механических показателей плательных тканей является основой для разработки рекомендаций по выбору тканей для изготовления платьев с разнообразной отделкой.

Ключевые слова: декор, физикомеханические свойства ткани, фешниндустрия, 3D печать, поверхностная плотность.

ІНФОРМАЦІЯ ПРО АВТОРІВ: https://doi.org/10. 30857/26170272.2019.4.7.
Пашкевич Калина Лівіанівна, д-р техн. наук, професор, професор кафедри ергономіки і проектування одягу, Київський національний університет технологій та дизайну, ORCID 0000-0001-6760-3728, Scopus 57191851112, e-mail: kalina.pashkevich@gmail.com

Єжова Ольга Володимирівна, д-р пед. наук, професор, професор кафедри теорії і методики технологічної підготовки, охорони праці та безпеки життєдіяльності, Центральноукраїнський державний педагогічний університет імені Володимира Винниченка, ORCID 0000-0002-5920-1611, Scopus 57200291293, e-mail: oyezhova70@gmail.com

Кротова Тетяна Федорівна, д-р мист., доцент, професор кафедри художнього моделювання костюма, Київський національний університет технологій та дизайну, ORCID 0000-0001-6367-0317, e-mail: krotova_t@ukr.net

Креденець Неля Дмитрівна, д-р пед. наук, доцент, директор Львівського коледжу індустрії моди Київського національного університету технологій та дизайну, професор кафедри ергономіки і проектування одягу, Київський національний університет технологій та дизайну, ORCID 0000-0003-0221-9017, e-mail: Idtlp@mail.lviv.ua

Лю Цзянсінь, аспірантка, факультет дизайну, Київський національний університет технологій та дизайну, ORCID 0000-0002-6805-692X, e-mail: kathyliu511@aliyun.com

Фесюк Іванна Ярославівна, магістр, Київський національний університет технологій та дизайну, ORCID 0000-0003-0709-9296, e-mail: fesiuk.ivanna@gmail.com

Цитування за ДСТУ: Пашкевич К. Л., Єжова О. В., Кротова Т.Ф., Креденець Н.Д., Лю Цзянсінь, Фесюк І.Я. Дизайн-проектування сучасних суконь з оздобленням 3 урахуванням властивостей тканин. Art and design. 2019. №4. С. 79-90.

Citation APA: Pashkevych, K. L., Yezhova, O. V., Krotova T.F., Kredenets N.D., Liu Jiangxin, Fesyuk I.Ya. (2019) Design-projection of modern dresses with finishing, considering the properties of fabrics. Art and design. 4. 79-90. 